Jurnal PINUS: Jurnal Penelitian Inovasi Pembelajaran, 5 (2), 2020, 39-56

Available online at: http://ojs.unpkediri.ac.id/index

DOI: https://doi.org/10.29407/pn.v5i2.14539

\title{
Hubungan Strategi Umpan Balik (Feedback), Motivasi Berprestasi dan Hasil Belajar Dalam Pembelajaran PPKn di SMK
}

\author{
Sumarno \\ sumarno@smkn5malang.sch.id \\ Guru PPKn SMK Negeri 5 Malang
}

\begin{abstract}
Abstrak
Gagne (1985) dan Marzano (2004), menyatakan bahwa salah satu kegiatan penting dalam pembelajaran yang efektif adalah pemberian umpan balik terhadap hasil evaluasi atau tugas-tugas yang dikerjakan siswa. Penelitian ini bertujuan menguji pengaruh pemberian umpan balikterhadap hasil belajar (pemahaman dan penerapan konsep) pada siswa yang memiliki motivasi berprestasi berbeda dalam pembelajaran Pendidikan Pancasila dan Kewarganegaraan di SMK. Penelitian ini menggunakan rancangan penelitian eksperimen semu (Quasi Experiment). Subjek penelitian ini siswa SMK Negeri 5 Malang sebanyak 126 siswa. Instrumen penelitian yang digunakan untuk mengumpulkan data adalah kuesioner motivasi berprestasi dan alat uji tes pemahaman dan penerapan konsep. Data penelitian dianalisis menggunakan metode MANOVA (Multivariate Analysis of Variance) dengan faktorial $2 \times 2$. Hasil temuan penelitian yaitu: (1) terdapat perbedaan hasil belajar (pemahaman dan penerapan konsep) antara kelompok siswa yang diberi perlakuan umpan balik langsung (segera) dan tidak langsung (tertunda); (2) terdapat perbedaan hasil belajar (pemahaman dan penerapan konsep) antara kelompok siswa bermotivasi berprestasi rendah dan tinggi dan (3) interaksi umpan balik dengan motivasi berprestasi tidak berpengaruh secara simultan terhadap hasil belajar pemahaman dan penerapan konsep dalam pembelajaran PPKn di SMK
\end{abstract}

Kata Kunci: Umpan balik (feedback), motivasi berprestasi dan hasil belajar

\begin{abstract}
Gagne (1985) and Marzano (2004), state that one of the important activities in effective learning is giving feedback on the results of evaluations or assignments that students work on. This study aims to examine the effect of providing feedback on learning outcomes (understanding and application of concepts) to students who have different achievement motivations in learning Pancasila and Citizenship Education in SMK. This study uses a quasi-experimental research design (Quasi Experiment). The subjects of this study were 126 students of SMK Negeri 5 Malang. The research instrument used to collect data was an achievement motivation questionnaire and a test of understanding and applying concepts. The research data were analyzed using the MANOVA (Multivariate Analysis of Variance) method with $2 \times 2$ factorial. The research findings are: (1) there are differences in learning outcomes (understanding and application of concepts) between groups of students who are given direct (immediate) and indirect (delayed) feedback treatment; (2) there are differences in learning outcomes (understanding and application of concepts) between groups of students who are low and high achievers and (3) the interaction of feedback with achievement motivation does not have a simultaneous effect on the learning outcomes of understanding and application of concepts in teaching PPKn in $S M K$.
\end{abstract}

Keywords: Feedback, achievement motivation and learning outcom 
Jurnal PINUS: Jurnal Penelitian Inovasi Pembelajaran, 5 (2), 2020, Sumarno

\section{PENDAHULUAN}

Permasalahan

pembelajaran

Pancasila

umum

Kewarganegaraan (PPKn) di Sekolah

Menengah Kejuruan (SMK) berdasarkan pengamatan dan pengalaman penulis sebagai pendidik adalah kesenjangan hasil belajar kognitif "pemahaman" dan "penerapan” konsep. Capaian hasil belajar kognitif pemahaman konsep tidak seimbang dengan capaian hasil penerapan konsep. Peserta didik memahami konsepkonsep berkaitan dengan Pancasila dan kewarganegaraan, namun tidak mampu menggunakan konsep untuk menganalisis berbagai fenomena yang terjadi di masyarakat. Contoh, peserta didik telah memahami definisi konsep "keadilan" tetapi peserta didik tidak mampu membedakan situasi dan kondisi yang "berkeadilan" dan "tidak berkeadilan" dalam masyarakat. Kesenjangan hasil belajar tersebut diperkuat hasil ulangan harian, ulangan tengah semester dan ulangan akhir semester selalu dibawah kriteria ketuntasan belajar (KKM). Pembelajaran Pancasila dan Kewarganegaraan di sekolah dianggap kurang efektif, pembelajaran masih bersifat indoktrinatif-normatif, aktivitas peserta didik berpikir kritis, positif, konstruktif dan produktif sangat terbatas, serta kurang menumbuhkan kesadaran nilai-nilai luhur yang membimbing peserta didik menuju manusia berakhlak mulia. Kesenjangan hasil belajar pemahaman dan penerapan konsep diduga sebagai dampak pembelajaran tidak efektif.

Pembelajaran yang efektif didalamnya terdapat sembilan kegiatan penting (Gagne, 1985 dan Marzano, 2004), kegiatan penting tersebut diantaranya adalah pemberian umpan balik terhadap hasil evaluasi atau tugastugas yang dikerjakan siswa. Pemberian umpan balik adalah pemberian informasi kepada peserta didik yang bertujuan memodifikasi pemikiran atau perilaku peserta didik agar dapat melakukan perbaikan kualitas capaian hasil pembelajaran (Shute, J. Valerie, 2008:154). Pertanyaannya adalah apakah terdapat hubungan antara pemberian umpan balik, motivasi berprestasi dan hasil belajar peserta didik? Beberapa hasil penelitian menghasilkan informasi umum bahwa pemberian umpan balik berhubungan dengan pemerolehan hasil belajar peserta didik. Umpan balik berhubungan dengan perbaikan prestasi dan berfungsi untuk memotivasi para pembelajar dalam pembelajaran (Shute, Valerie. J. 2008:2). Para peneliti menyampaikan informasi hasil penelitian yang berbeda-beda mengenai hubungan variable umpan balik, motivasi berprestasi dan hasil belajar. Temuan penelitian yang berbeda-beda mengindikasikan pentingnya dilakukan penelitian kajian lanjut tentang umpan balik, motivasi belajar dan hasil belajar. Penelitian terdahulu penelitian umpan balik dihubungkan dengan variabel hasil pembelajaran, oleh karena itu perlu dikembangkan kajian variabel umpan balik dihubungkan dengan variabelvariabel lain yang berpengaruh terhadap hasil pembelajaran. Penelitian ini akan mengkaji hubungan strategi pemberian umpan balik, motivasi berprestasi dan hasil belajar kemampuan pemahaman dan 
Jurnal PINUS: Jurnal Penelitian Inovasi Pembelajaran, 5 (2), 2020, Sumarno

penerapan konsep. Strategi umpan balik sebagai variabel bebas, hasil belajar pemahaman dan penerapan konsep sebagai variabel terikat serta motivasi berprestasi sebagai variabel moderator. Perbedaan penelitian yang kan dilakukan ini dengan penelitian terdahulu adalah model pembelajaran yang dijadikan konteks penelitian ditentukan yaitu model inkuiri jurisprudensi. Permasalahan penelitian yang menjadi pusat perhatian adalah apakah pemberian umpan balik berpengaruh terhadap hasil belajar (pemahaman dan penerapan konsep) pada peserta didik yang memiliki motivasi berprestasi berbeda dalam pembelajaran Pendidikan Pancasila dan Kewarganegaraan dengan model inkuri jurisprudensi? Tujuan penelitian adalah menguji dan mengetahui apakah terdapat: (1) perbedaan hasil belajar (pemahaman dan penerapan konsep) antara kelompok peserta didik yang diberi perlakuan strategi umpan balik langsung dan tidak langsung; (2) perbedaan hasil pemahaman dan penerapan konsep antara kelompok peserta didik bermotivasi berprestasi tinggi dan rendah dan (3) pengaruh interaksi umpan balik dan motivasi berprestasi terhadap hasil belajar (pemahaman dan penerapan konsep) dalam pembelajaran Pendidikan Pancasila dan Kewarganegaraan (PPKn) di SMK.

Kajian pustaka berkaitan dengan konsep variabel dalam penelitian ini secara berurutan diuraikan yaitu umpan balik (feedback) pembelajaran, motivasi berprestasi dan hasil belajar PPKn berupa pemahaman dan penerapan konsep serta interaksi umpan balik dengan motivasi berprestasi dalam pembelajaran.

\section{Umpan balik (Feedback) Pembelajaran}

Umpan balik dalam penelitian ini adalah informasi yang dikomunikasikan kepada peserta didik untuk memodifikasi pemikiran atau perilaku agar bisa memperbaiki kualitas hasil pembelajaran. Umpan balik juga dapat didefinisikan sebagai sebuah proses di mana faktorfaktor yang menciptakan hasil dapat dimodifikasi, dikoreksi, dan diperkuat. Strategi umpan balik yang akan dikaji dalam penelitian ini adalah strategi langsung (immediate feedback) dan strategi tidak langsung (delayed feedback) yang diadaptasi dari Shute, J. Valerie (2008:154).

Strategi umpan balik langsung didefinisikan sebagai umpan balik yang segera diberikan setelah pembelajar memberikan respons atau menyelesaikan tugas. Sedangkan strategi tidak langsung didefinisikan sebagai lawan dari langsung, yaitu umpan balik yang diberikan beberapa jam, beberapa minggu atau sekian lama setelah selesainya sebuah tugas atau ulangan. Perbedaan penggunaan umpan balik dengan strategi langsung dan tidak langsung diduga mempengaruhi hasil pembelajaran. Kapan waktu yang tepat penyampaian umpan balik pengaruhnya tidak diketahui secara pasti, tetapi ada interaksi antara waktu penyampaian umpan balik dan hasil belajar. Beberapa hasil penelitian memberikan bahwa strategi umpan balik langsung lebih efektif karena dapat mencegah agar kesalahan tidak tertanam dalam memori 
Jurnal PINUS: Jurnal Penelitian Inovasi Pembelajaran, 5 (2), 2020, Sumarno

pembelajar, sedangkan hasil penelitian yang lain memberikan informasi bahwa strategi umpan balik tidak langsung dapat mereduksi kesalahan dilupakan dan informasi yang benar bisa disimpan tanpa ada gangguan. Penggunaan umpan balik strategi langsung mengajukan teori bahwa semakin cepat informasi korektif diberikan, maka semakin besar kemungkinannya akan menghasilkan sebuah retensi yang efisien. Kelebihan umpan balik strategi langsung dibandingkan dengan umpan balik tidak langsung atau tertunda diketahui dari pemerolehan materi informasi, keterampilan prosedural, dan beberapa keterampilan.

Pendukung penggunaan strategi tidak langsung (delayed feedback) umumnya mengacu pada hipotesis bahwa kesalahan awal tidak berhubungan dengan jawaban benar yang akan dipelajari jika informasi korektif ditunda dan kesalahan akan mudah dilupakan. Umpan balik yang disampaikan secara tidak langsung lebih efektif untuk meningkatkan transfer belajar, khususnya dalam kaitannya dengan tugas pembentukan konsep. Umpan balik yang disampaikan secara langsung lebih efisien khususnya untuk jangka pendek dan untuk keterampilan prosedural. Hasil eksperimen menunjukkan bahwa waktu penundaan yang lebih lama antara satu umpan balik dengan lainnya menciptakan kinerja yang lebih buruk selama fase pemerolehan tetapi menciptakan retensi yang lebih bagus jika dibandingkan dengan kondisi dengan penundaan yang lebih pendek.
Umpan balik pembelajaran dapat diberikan dalam bentuk verifikasi dan elaborasi. Umpan balik berbentuk verifikasi adalah berupa penilaian sederhana tentang apakah sebuah jawaban benar atau tidak, dan umpan balik berbentuk elaborasi adalah berupa petunjuk yang relevan untuk memandu siswa memperoleh jawaban yang benar. Umpan balik yang efektif mencakup elemen-elemen verifikasi dan elaborasi. Umpan balik berbentuk verifikasi atau koreksi dapat dikomunikasikan dengan beberapa cara untuk mengkonfirmasikan apakah sebuah jawaban benar atau salah. Umpan balik verifikasi dapat dengan cara menyatakan "benar" atau "salah". Teknik umpan balik verifikasi dapat diberikan dengan penebalan atau memberi nilai pada sebuah jawaban untuk menunjukkan kebenarannya (misalnya dengan tanda check) atau memberikan informasi tertentu pada siswa. Umpan balik berbentuk elaborasi memiliki variasi yang lebih banyak daripada umpan balik verifikasi. Sebagai contoh, (a) menjelaskan sebuah topik, (b) menjelaskan sebuah respons, (c) mendiskusikan kesalahan tertentu, (d) memberikan contoh yang sudah dikerjakan, atau (e) memberikan panduan. Para peneliti sepakat bahwa satu jenis elaborasi, umpan balik yang spesifik untuk respons tertentu bisa meningkatkan prestasi siswa, khususnya efisiensi belajar, dan itu lebih bagus dari jenis umpan balik lainnya seperti misalnya verifikasi sederhana atau "jawab sampai benar"

Tujuan pemberian umpan balik adalah meningkatkan pengetahuan, 
Jurnal PINUS: Jurnal Penelitian Inovasi Pembelajaran, 5 (2), 2020, Sumarno

keterampilan dan pemahaman siswa tentang keterampilan umum atau bidang tertentu, misalnya pemecahan masalah, dan berbagai macam jenis umpan balik bisa digunakan untuk tujuan lain, misalnya umpan balik diarahkan pada tujuan melakukan perbaikan tugas tertentu dan langsung diberikan. Black dan William (1998), menyatakan ada dua fungsi utama dari umpan balik: yaitu fungsi direktif dan fasilitatif. Umpan balik direktif adalah umpan balik yang memberitahu siswa apa yang harus diperbaiki atau direvisi. Umpan balik jenis direktif cenderung lebih spesifik jika dibandingkan dengan feedback fasilitatif, yang memberikan komentar dan saran untuk membantu siswa ketika melakukan revisi dan konseptualisasi.

Efek konstruktif umpan balik (Mory, 1995) dalam proses belajar, yaitu: (1) membantu siswa mengkonstruksi realitas internal dengan memberikan sarana intelektual, (2) membantu siswa memecahkan masalah dalam seting kontekstual; (3) muncul dalam bentuk negosiasi antar teman, (4) memberikan panduan untuk model representasi, (5) memandu siswa melalui domain yang tidak terstruktur, dan mengingatkan siswa tentang tujuannya dan (6) menantang siswa untuk terus berkembang.

\section{Motivasi Berprestasi}

Motivasi berprestasi didefinisikan sebagai usaha mencapai sukses atau berhasil dalam kompetisi dengan suatu ukuran keunggulan yang dapat berupa prestasi orang lain maupun prestasi sendiri (Mc. Clelland, 1987:40). Lindgren (1976: 67) mengemukakan hal senada bahwa motivasi berprestasi sebagai suatu dorongan yang ada pada seseorang sehubungan dengan prestasi, yaitu menguasai, memanipulasi serat mengatur lingkungan sosial maupun fisik, mengatasi segala rintangan dan memelihara kualitas kerja yang tinggi, bersaing melalui usaha-usaha untuk melebihi hasil kerja yang lampau, serta mengungguli hasil kerja yang lain.

$$
\text { Heckhausen }
$$

mendeskripsikan motivasi berprestasi sebagai usaha untuk meningkatkan atau melakukan kecakapan pribadi setinggi mungkin dalam segala aktivitas dan suatu ukuran keunggulan tersebut digunakan sebagai pembanding, meskipun dalam usaha melakukan aktivitas tersebut ada dua kemungkinan yakni gagal atau berhasil. Motivasi berprestasi merupakan motif yang mendorong individu untuk mencapai sukses dan bertujuan untuk berhasil dalam kompetisi dengan beberapa ukuran keunggulan (standard of excellence). Ukuran keunggulan digunakan untuk standar keunggulan prestasi dicapai sendiri sebelumnya dan layak seperti dalam suatu kompetisi. Dalam teori expectancy-value Atkinson (1960: 56) mengemukakan bahwa motivasi berprestasi seseorang didasarkan atas dua hal yaitu, adanya tendensi untuk meraih sukses dan adanya tendensi untuk menghindari kegagalan. Pada dasarnya keadaan motif itu dimiliki oleh individu, namun keduanya mempunyai keadaan berbeda-beda dalam berbagai situasi dan kondisi menurut adanya prestasi. Atkinson (1958:34) mengemukakan bahwa keberhasilan individu untuk mencapai keberhasilan 
Jurnal PINUS: Jurnal Penelitian Inovasi Pembelajaran, 5 (2), 2020, Sumarno

dan memenangkan persaingan berdasarkan standar keunggulan, sangat terkait dengan tipe kepribadian yang memiliki motif berprestasi lebih tinggi daripada motif untuk menghindari kegagalan begitu pula sebaliknya, apabila motif menghindari terjadinya kegagalan lebih tinggi daripada motif sukses, maka motivasi berprestasi seseorang cenderung rendah. Dari uraian tersebut dapat disimpulkan bahwa motivasi berprestasi merupakan suatu dorongan yang berhubungan dengan bagaimana melakukan sesuatu dengan lebih baik, lebih cepat, lebih efisien dibandingkan dengan apa yang telah dilakukan sebelumnya, sebagai usaha mencapai sukses atau berhasil dalam kompetisi dengan suatu ukuran keunggulan yang dapat berupa prestasi orang lain maupun prestasi sendiri.

David Mc Clelland (1978:77) mengemukakan bahwa individu yang mempunyai motivasi berprestasi yang tinggi terdapat lima karakteristik, yaitu: (1) perasaan yang kuat untuk mencapai tujuan, yaitu keinginan untuk menyelesaikan tugas dengan hasil yang sebaik-baiknya. (2) Bertangungjawab, yaitu mampu bertanggungjawab terhadap dirinya sendiri dan menentukan masa depannya, sehingga yang dicita-citakan berhasil tercapai. (3) Evaluatif, yaitu menggunakan umpan balik untuk menentukan tindakan yang lebih efektif guna mencapai prestasi, kegagalan yang dialami tidak membuatnya putus asa, melainkan sebagai pelajaran untuk berhasil. (4) Mengambil risiko "sedang", dalam arti tindakan-tindakannya sesuai dengan batas kemampuan yang dimilikinya. (5) Kreatif dan inovatif, yaitu mampu mencari peluang-peluang dan menggunakan kesempatan untuk dapat menunjukkan potensinya Adapun individu bermotivasi prestasi rendah memiliki karakteristik yang bertolak belakang dengan karakteristik individu bermotivasi prestasi tinggi sebagaimana diuraikan diatas.

\section{Hasil Belajar: Pemahaman dan Penerapan Konsep}

Hasil belajar "pemahaman" adalah kemampuan mengkonstruksi makna dari pesan-pesan pembelajaran, baik yang bersifat lisan, tulisan ataupun grafis yang disampaikan melalui pengajaran, buku, atau layar komputer (Anderson, L.W dan Krathwohl, D.R. 2001:105). Taksonomi kemampuan memahami meliputi kemampuankemampuan sebagai berikut: menafsirkan, mencontohkan, mengklasifikasikan, merangkum, menyimpulkan, membandingkan dan menjelaskan. Kemampuan menafsirkan terjadi ketika peserta didik mengubah informasi dari satu bentuk ke bentuk yang lain, misalnya dari bentuk kata menjadi gambar atau sebaliknya. Kemampuan mencontohkan adalah kemampuan mengidentifikasi ciri-ciri pokok dari konsep atau prinsip umum dan menggunakan ciri-ciri tersebut untuk membuat contoh lain. Kemampuan mengklasifikasikan adalah proses kognitif yang melengkapi proses mencontohkan. Jika mencontohkan dimulai dari konsep atau prinsip umum kemudian menemukan contoh, mengklasifikasikan dimulai dengan contoh tertentu dengan mengharuskan 
Jurnal PINUS: Jurnal Penelitian Inovasi Pembelajaran, 5 (2), 2020, Sumarno

menemukan konsep atau prinsip umumnya. Kemampuan merangkum adalah kemampuan mengemukakan satu kalimat yang mempresentasikan informasi yang diterima atau mengabstraksikan sebuah tema. Kemampuan menyimpulkan terjadi ketika peserta didik dapat mengabstraksikan sebuah konsep atau prinsip beserta contoh-contoh dengan mencermati ciri-ciri setiap contoh serta menarik hubungan antara ciri-ciri pada contoh. Kemampuan membandingkan adalah kemampuan menditeksi persamaan dan perbedaan antar dua obyek, peristiwa, ide, masalah, atau situasi yang terjadi. Kemampuan menjelaskanadalah kemampuan menggunakan model sebab akibat dalam sebuah system dan model diturunkan dari teori, hasil penelitian, atau pengalaman peserta didik.

Model pemahaman konsep diciptakan oleh Bruner (Degeng, 2013:115) secara berulang digunakan istilah-istilah, seperti: contoh, kriteria, dan atribut atau karateristik untuk melukiskan kegiatan-kegiatan mengkategori dan pemahaman konsep. Bruner (1980) memandang bahwa suatu konsep memiliki lima unsur dan seseorang dikatakan memahami suatu konsep apabila mengetahui semua unsur dari konsep itu. Kelima unsur ini adalah: nama, contoh-contoh positif dan negatif, karakteristik pokok maupun tidak, rentangan karakteristik, dan kaidah. Gagne dalam Degeng (2013:93) menyatakan bahwa pemahaman konsep sebagai keterampilan intelektual dikatagorikan menjadi dua macam yaitu konsep konkret dan konsep abstrak. Pembelajar belajar konsep konkret apabila dapat mengidentifikasi contohcontoh baru atau yang belum dipelajari dari sekelompok objek atau kelompokkelompok objek. Konsep konkret diidentifikasi menunjuk ke, atau menandai pada, contoh-contoh, dan biasanya tidak dapat diidentifikasi dengan definisi. Konsep abstrak, dikatakan belajar konsep abstrak apabila pembelajar menggunakan definisi untuk mengklarifikasi contoh-contoh yang tidak dipelajari sebelumnya.

Bruner mengembangkan strategistrategi yang berbeda untuk mencapai jenis konsep yang berbeda. Ada tiga strategi pengorganisasian pembelajaran pemahaman konsep yang telah dikembangkan, yaitu: (1) model penerimaan, (2) model pilihan, dan (3) model contoh yang tak terorganisasi. Model penerimaan mengacu kepada strategi pengorganisasian contoh-contoh konsep dengan memberi tanda "ya", bila contoh itu merupakan contoh konsep, dan tanda "tidak" bila contoh itu bukan merupakan contoh konsep. Model pilihan mengacu pada strategi pengorganisasian contoh-contoh konsep tanpa memberi tanda "ya" atau "tidak". Model dengan contoh yang tidak terorganisasi mengacu kepada strategi pemahaman konsep dengan menggunakan contoh-contoh yang tak terorganisasi dalam lingkungan kehidupan yang sesungguhnya.

Hasil belajar "penerapan" atau "aplikasi" adalah hasil berbentuk kemampuan menggunakan prosedurprosedur tertentu untuk menyelesaikan soal latihan atau menyelesaikan masalah 
Jurnal PINUS: Jurnal Penelitian Inovasi Pembelajaran, 5 (2), 2020, Sumarno

(Anderson, Lorin W dan Krathwohl, David. R. 2001:116). Soal latihan adalah tugas yang prosedur penyelesaiannya sudah diketahui peserta didik. Masalah adalah tugas yang prosedur penyelesaiannya belum diketahui peserta didik. Hasil belajar kategori penerapan terdiri dari dua proses kognitif, yakni mengeksekusi

dan mengimplementasikan.

Kategori mengeksekusi jika tugas hanya soal latihan dan kategori mengimplementasikan jika tugas merupakan penyelesaian masalah. Hasil belajar kognitif domain aplikasi kategori mengeksekusi, diterapkan apabila tugas belajar berupa soal latihan yang sudah familier, pada umumnya siswa sudah memiliki pengetahuan prosedural yang harus digunakan. Misalnya, siswa belajar menyusun lembaga-lembaga tinggi negara sesuai konstitusi UUD 1945. Akan tetapi untuk aplikasi kategori implementasi diterapkan apabila tugas belajar berupa masalah, siswa harus menentukan jenis pengetahuan yang digunakan untuk memecahkan masalah. Untuk menyelesaikan masalah, siswa mungkin melakukan modifikasi pengetahuan prosedural yang sudah dimiliki. Misalnya, siswa belajar menganalisis faktor penyebab terjadinya perbuatan melanggar hukum. Penerapan kategori mengimplementasikan, memahami pengetahuan prosedural merupakan prasyarat untuk dapat mengaplikasikan pengetahuan prosedural.

Konsep menurut Dick \& Carey (2004) adalah obyek, simbol, situasi yang dapat dikelompokan satu dengan lainya berdasarkan satu atau lebih karakteristik yang dimiliki dan biasanya diidentikkan dengan nama atau simbol. Konsep berdasarkan bentuknya diklasifikasikan menjadi dua jenis, yaitu: konsep berdasarkan pengamatan dan berdasarkan definisi. Konsep merupakan abstraksi dari hasil pengalaman konkret (Gagne, 1989. Abstraksi dilakukan dengan mengambil ciri-ciri objek yang menjadi perhatian dan membuang ciri-ciri yang tidak relevan. Konsep dipelajari dari persepsi terhadap objek-objek dikuatkan oleh pengalaman yang telah dimiliki sebelumnya (prior knowledge). Konsep berdasarkan definisi adalah konsep yang berbentuk rumusan verbal menggunakan kata-kata atau kalimat.

\section{Interaksi Umpan Balik dan Motivasi Berprestasi dalam Pembelajaran}

Hubungan antara variabel umpan balik, motivasi berprestasi dan hasil belajar dapat dijelaskan dari berbagai teori tentang belajar. Berdasarkan sudut pandang teori behaviorist, belajar didefinisikan sebagai sebuah pengkondisian di mana perilaku yang diikuti dengan penguat (reinforce) akan mengalami peningkatan frekuensi atau probabilitasnya (Operant conditioning dari Skinner). Umpan balik guru kepada peserta didik dipandang sebagai penguatan, dengan tujuan untuk membantu pembelajar berkembang dari menguasai prosedur penyelesaian tugastugas sederhana ke tugas-tugas yang kompleks sifatnya. Dasar pemikiran dari kaum behaviorist tersebut bisa dilihat dengan jelas, yaitu adanya umpan balik yang berasal dari sumber eksternal untuk bisa menyesuaikan hasil belajar eksternal 
Jurnal PINUS: Jurnal Penelitian Inovasi Pembelajaran, 5 (2), 2020, Sumarno

dengan performa pembelajar untuk tugastugas tertentu. Pandangan umum umpan balik dianggap sebagai motivator atau insentif untuk meningkatkan respons dan/atau akurasi (Kulhavy dan Wager, 1993).

Pandangan yang menyatakan bahwa umpan balik berfungsi sebagai motivator atau insentif untuk pembelajaran masih tetap berlaku di kelas-kelas hungga sekarang, tetapi muncul kebingungan untuk membedakan antara pujian dan umpan balik yang terkait dengan isi pembelajaran (Hattie dan Timperley, 2007). Deci, Koester dan Ryan (1999) menemukan bahwa ketika guru memberikan penghargaan dalam bentuk konkret sebagai sebuah umpan balik, maka motivasi intrinsik tereduksi secara signifikan dan siswa enggan untuk memotivasi atau mengatur diri sendiri. Umpan balik sebagai penghargaan ekstrinsik seringkali mendorong siswa untuk lebih mementingkan insentif, yang akhirnya menyebabkan semakin tingginya intensitas kompetisi dan bukan tingginya keterlibatan dalam pembelajaran.

Narciss dan Huth (2004) menjelaskan bahwa umpan balik yang efektif yaitu umpan balik yang didesain dengan mengaitkan pada variabelvariabel penting lain dalam proses belajar yaitu variabel Pembelajar dan "pembelajaran". Variabel pembelajaran atau konteks terdiri dari tiga elemen utama: (a) tujuan pembelajaran (misalnya sasaran belajar atau standar yang terkait dengan kurikulum), (b) tugas belajar (misalnya item pengetahuan, operasi kognitif, keterampilan meta kognitif) dan (c) silapan dan hambatan (misalnya silapan yang biasanya dilakukan, strategi yang salah, sumber kesalahan). Variabel peserta didik meliputi informasi tentang peserta didik yang relevan dengan desain umpan balik (feedback) mencakup (a) tujuan dan sasaran belajar, (b) pengetahuan sebelumnya, keterampilan dan kemampuan (misalnya yang bergantung pada domain, seperti misalnya pengetahuan tentang pokok materi, dan bergantung pada domain, seperti misalnya keterampilan meta kognitif) dan (c) motivasi akademis (misalnya, kebutuhan seseorang untuk prestasi akademis, cakapan diri akademis, dan keterampilan meta motivasional). Sedangkan variabel umpan balik terdiri dari tiga elemen utama: (a) kandungan umpan balik (yaitu aspek evaluatif, seperti misalnya verifikasi, dan aspek informatif, misalnya petunjuk, analog, penjelasan dan contoh yang sudah dijelaskan), (b) fungsi umpan balik (yaitu kognitif, meta kognitif, dan motivasional) dan (c) presentasi komponen umpan balik (misalnya timing, jadwal dan mungkin pertimbangan adaptivitas).

\section{METODE}

Rancangan penelitian yang digunakan adalah rancangan eksperimen semu (quasi-experiment) jenis pretest non equivalen control group dengan faktorial $2 \times 2$. Rancangan penelitian ini dipilih karena kelompok eksperimen dan kelompok kontrol subjek penelitian tidak dapat dilakukan pemilihan atau seleksi secara random individual melainkan sudah dalam keadaan berkelompok (intact group) dan kedua kelompok 
Jurnal PINUS: Jurnal Penelitian Inovasi Pembelajaran, 5 (2), 2020, Sumarno

tersebut sama-sama diberikan perlakuan pretest dan postest.

Subjek penelitian adalah peserta didik sekolah menengah kejuruan (SMK). Penelitian dilaksanakan di SMK Negeri 5 Malang yang berlokasi di Jl. Ikan Piranha Atas, Kelurahan Tunjungsekar, Kecamatan Lowokwaru Kota Malang. Jumlah keseluruhan peserta didik pada tahun ajaran 2016/2017 adalah 2198 anak yang dikelompokan menjadi 61 rombongan belajar. Subyek untuk penelitian ini adalah peserta didik kelas $\mathrm{X}$ berjumlah 680 anak yang terbagi menjadi 22 rombongan belajar atau kelas. Sampel penelitian diambil dengan teknik sampling Cluster Random Sampling sebanyak empat (4) rombel atau kelas dengan jumlah keseluruhan 126 peserta didik. Rombongan belajar terpilih 1 dan 2 atau berjumlah 60 peserta didik dijadikan kelompok eksperimen dan rombongan belajar 3 dan 4 dijadikan atau berjumlah 67 peserta didik dijadikan sebagai kelompok kontrol.

Instrumen untuk mengumpulkan data penelitian adalah kuesioner motivasi berprestasi dan soal tes pemahaman dan penerapan konsep. Data penelitian yang dikumpulkan dianalisis dengan teknik MANOVA yaitu Uji t dan Uji F. Teknik Uji $\mathrm{t}$ atau uji parsial digunakan untuk menguji bagaimana pengaruh masingmasing variabel bebas secara sendirisendiri terhadap variabel terikat. Teknik Uji $F$ atau uji serentak digunakan untuk menguji bagaimanakah pengaruh semua variabel bebas secara bersama-sama terhadap variabel terikat.
Perlakuan terhadap subyek kelompok eksperimen dan kelompok kontrol adalah sebagai berikut: (1) memberikan pretest kepada kelompok eksperimen dan kontrol; (2) kelompok eksperimen dan kontrol menjawab pertanyaan angket motivasi berprestasi; (3) kelompok eksperimen dan kontrol diberi pembelajaran dengan model yang sama yaitu Inkuiri Jurisprudensi dan diberikan tugas; (4) kelompok eksperimen diberi umpan balik dengan strategi langsung setelah menyelesaikan tugas dan melakukan perbaikan, sedangkan kelompok kontrol diberi umpan balik tugas dengan strategi tidak langsung yaitu setelah menyelesaikan tugas dikumpulkan dan umpan balik dikomunikasikan pada pertemuan berikutnya; dan (5) memberikan postest pada subyek kelompok eksperimen dan kontrol setelah dilakukan 8 kali pembelajaran pada kedua kelompok.

\section{HASIL PENELITIAN}

Hasil penelitian pengaruh umpan balik dan motivasi berprestasi terhadap hasil belajar (pemahaman dan penerapan konsep) pada pembelajaran Pendidikan Pancasila dan Kewarganegaraan degan model inkuiri jurisprudensi di sekolah menengah kejuruan adalah sebagai berikut: pertama, ditemukan perbedaan hasil belajar pemahaman konsep antara kelompok peserta didik yang diberi perlakuan umpan balik langsung dan tidak langsung, berdasarkan rata-rata skor hasil postest kedua kelompok. Rata-rata skor pemahaman kelompok perlakuan strategi umpan balik langsung adalah 64.8000 dan kelompok perlakuan umpan balik 
Jurnal PINUS: Jurnal Penelitian Inovasi Pembelajaran, 5 (2), 2020, Sumarno

tidak langsung adalah 65.557. Selisih rata-rata skor kedua model umpan balik adalah 0.757 .

Kedua, ditemukan perbedaan pemahaman konsep antara kelompok siswa yang bermotivasi berprestasi tinggi dan rendah. Rata-rata skor pemahaman konsep pada kelompok siswa bermotivasi berprestasi tinggi adalah 65.4821 dan pada kelompok motivasi berprestasi rendah adalah 64.8261. Selisih rata-rata skor kelompok siswa bermotivasi berprestasi tinggi dan rendah adalah 0.656 .

Ketiga, tidak ditemukan pengaruh interaksi umpan balik dan motivasi berprestasi terhadap hasil belajar pemahaman konsep. Variabel umpan balik dan motivasi berprestasi masingmasing memiliki pengaruh yang signifikan secara simultan terhadap variabel hasil belajar pemahaman konsep. Hasil pengujian ada tidaknya pengaruh interaksi strategi umpan balik dan motivasi berprestasi terhadap variabel pemahaman konsep menunjukkan bahwa angka signifikan (sig) yang diperoleh pada skor pemahaman konsep sebesar 0.639 dan acuan nilai sig $>0.05$ sehingga disimpulkan bahwa tidak ada interaksi yang bermakna antara umpan balik dan motivasi terhadap hasil belajar pemahaman konsep. Variabel umpan balik dan motivasi masing-masing berpengaruh secara parsial terhadap pemahaman konsep.

Keempat, ditemukan perbedaan hasil belajar penerapan konsep antara kelompok yang diberi perlakukan strategi umpan balik langsung dan tidak langsung. Rata-rata skor hasil postest pada kelompok strategi umpan balik langsung sebesar 67.2000 dan kelompok yang diberi perlakuan tidak langsung sebesar 51.1923. Selisih rata-rata skor kedua strategi adalah 16.0077. Hasil statistik menyatakan bahwa terdapat perbedaan yang bermakna $(\operatorname{sig}=0.000)$ pada skor hasil penerapan konsep antara kelompok perlakuan umpan balik langsung dengan kelompok umpan balik tidak langsung. .

Kelima, ditemukan perbedaan hasil belajar penerapan konsep antara kelompok siswa bermotivasi berprestasi tinggi dan rendah. Rata-rata skor postest pada kelompok siswa bermotivasi berprestasi tinggi adalah 64.7321dan kelompok bermotivasi rendah sebesar 52.108. Selisih rata-rata skor kedua kelompok adalah 12.6234. Perbedaan rata-rata skor pada kedua kelompok tersebut sangat nyata jika dibandingkan dengan skor pada pemahamanan konsep. Nilai signifikansi yang diperoleh 0.002 yang menguatkan hasil bahwa besarnya perbedaan skor sangat nyata. Jadi pada skor penerapan konsep antara kelompok motivasi berprestasi tinggi dan rendah terdapat perbedaan yang bermakna.

Keenam, tidak ditemukan pengaruh interaksi strategi umpan balik dan motivasi berprestasi terhadap variabel hasil belajar penerapan konsep. Variabel strategi umpan balik dan motivasi berprestasi masing-masing memiliki pengaruh yang signifikan secara simultan terhadap variabel hasil belajar penerapan konsep Hasil pengujian ada tidaknya pengaruh interaksi strategi umpan balik dan motivasi berprestasi terhadap variabel penerapan konsep 
Jurnal PINUS: Jurnal Penelitian Inovasi Pembelajaran, 5 (2), 2020, Sumarno

menunjukkan bahwa signifikansi yang diperoleh pada skor penerapan konsep sebesar 0.617 dan nilai sig > 0.05 sehingga disimpulkan bahwa tidak ada pengaruh yang bermakna interaksi strategi umpan balik dan motivasi terhadap variabel penerapan konsep. Strategi umpan balik dan motivasi berprestasi masing-masing berpengaruh parsial pada penerapan konsep.

\section{PEMBAHASAN}

Pembahasan hasil temuan penelitian ini diuraikan dalam perspektif teori dan empiris tentang pengaruh umpan balik (feedback) terhadap hasil belajar, pengaruh motivasi berprestasi terhadap hasil belajar dan pengaruh interaksi umpan balik dengan motivasi berprestasi terhadap hasil belajar.

\section{Pengaruh umpan balik terhadap hasil belajar}

Berdasarkan hasil uji statistik terdapat perbedaan hasil belajar pemahaman dan penerapan konsep kelompok siswa yang menerima perlakuan umpan balik langsung dengan kelompok umpan balik tidak langsung. Faktor-faktor diduga menjadi penyebab perbedaan adalah faktor model umpan balik yang digunakan guru. Mekanisme kognitif yang dipakai siswa untuk menggunakan umpan balik dalam pembelajaran adalah seperti uraian berikut ini.

Pertama, umpan balik dapat menunjukkan tingkatan kinerja terbaru dan tingkatan kinerja yang diharapkan. Umpan balik dapat menutupi kesenjangan tersebut dan memotivasi siswa untuk melakukan usaha lebih keras. Umpan balik bisa mereduksi ketidakpastian tentang keberhasilan atau ketidakberhasilan siswa melakukan sebuah tugas karena ketidakpastian seringkali tidak menyenangkan dan mengalihkan perhatian dari kinerja. Oleh karenanya menghilangkan ketidakpastian bisa meningkatkan motivasi dan memunculkan strategi tugas yang lebih efisien.

Kedua, umpan balik dapat mereduksi beban kognitif siswa, khususnya siswa tingkatan semenjana atau siswa yang bermasalah. Siswa-siswa bisa saja lelah secara kognitif selama pembelajaran karena tingginya tuntutan kinerja dan mereka memperoleh manfaat dari umpan balik suportif yang dirancang untuk menurunkan beban kognitif. Umpan balik berupa penyajian contohcontoh yang sudah dikerjakan mampu mengurangi beban kognitif pada siswa berkemampuan rendah yang menghadapi tugas pemecahan masalah yang sulit. Moreno (2004) menyatakan umpan balik berbentuk penjelasan untuk membantu siswa tingkat semenjana.

Ketiga, umpan balik dapat memberikan informasi yang berguna untuk mengoreksi strategi penyampaian tugas yang tidak tepat, kesalahan prosedural atau miskonsepsi. Efek umpan balik yang lain yaitu berfungsi sebagai sarana korektif apabila umpan balik disampaikan dalam bentuk yang lebih spesifik.

Temuan penelitian ini sejalan dengan hasil penelitian Shute V, J. 2008 Simpulan bahwa secara umum umpan balik tugas merupakan cara yang strategis dalam usaha memperbaiki pengetahuan dan pemerolehan kemampuan siswa. 
Jurnal PINUS: Jurnal Penelitian Inovasi Pembelajaran, 5 (2), 2020, Sumarno

Umpan balik berpengaruh pada prestasi dan dianggap sebagai faktor yang penting untuk memotivasi belajar. Bagaimana pengaruh umpan balik dalam pembelajaran bergantung pada teori belajar yang digunakan dalam pembelajaran, yaitu: behaviouristik, kognitif, konstruktif atau regulasi diri.

Pemberian umpan balik dalam perspektif teori behaviouristik dipandang sebagai penguatan (reinforcement), dengan tujuan untuk bisa membantu pembelajar dalam penyelesaian tugastugas sederhana ke tugas-tugas yang kompleks sifatnya Pemberian umpan balik atau feedback dalam perspektif teori kognitif menjelaskan bahwa umpan balik atau feedback berfungsi tidak hanya untuk memperkuat jawaban yang benar tetapi juga menjadi informasi korektif untuk membantu pembelajar mengoreksi atau memverifikasi kesalahan yang mereka lakukan. Pemberian umpan balik dalam perspektif teori konstruktif, feedback atau umpan balik merupakan bentuk interaksi antara siswa dan aktifitas belajar pemecahan masalah yang nyata dan sebagai sarana proses konstruktif. Pembelajar menggunakan umpan balik untuk membentuk, mengelaborasikan, dan menguji struktur mental sampai diperoleh struktur mental yang memuaskan, dan itu akan terus mengalami perubahan ketika pengalaman pembelajar berbenturan dengan informasi baru yang akhirnya memicu terjadinya restrukturisasi baru. Pemberian umpan balik atau feedback dalam perspektif teori regulasi diri memberikan penekanan pada pentingnya interaksi antara informasi feedback dan penerima serta memberikan penekanan pada keterlibatan aktif pembelajar untuk mencari petunjukpetunjuk dan memonitor serta mengevaluasi performa mereka sendiri.

Temuan penelitian ini menguatkan bahwa umpan balik guru dalam proses belajar mempunyai efek konstruktif (Mory, 1995), sebagai berikut: (1) membantu siswa mengkonstruksi realitas internal dengan memberikan sarana intelektual, (2) membantu siswa memecahkan masalah dalam seting kontekstual; (3) muncul dalam bentuk negosiasi antar teman, (4) memberikan panduan untuk model representasi, (5) memandu siswa melalui domain yang tidak terstruktur, dan mengingatkan siswa tentang tujuannya dan (6) menantang siswa untuk terus berkembang.

\section{Pengaruh motivasi berprestasi terhadap hasil belajar}

Berdasarkan hasil uji statistik terdapat perbedaan hasil belajar pemahaman dan penerapan konsep antara kelompok siswa bermotivasi berprestasi tinggi dengan kelompok bermotivasi prestasi rendah. Perbedaan rata-rata pada hasil belajar pemahaman tidak berbeda jauh antara dua kelompok perlakuan, sedangkan perbedaan signifikan terdapat pada hasil belajar penerapan konsep.

Dalam teori expectancy-value Atkinson (1960: 56) mengemukakan bahwa motivasi berprestasi seseorang didasarkan atas dua hal yaitu, adanya tendensi untuk meraih sukses dan adanya tendensi untuk menghindari kegagalan. Pada dasarnya keadaan motif itu dimiliki oleh individu, namun keduanya mempunyai keadaan berbeda-beda dalam 
Jurnal PINUS: Jurnal Penelitian Inovasi Pembelajaran, 5 (2), 2020, Sumarno

berbagai situasi dan kondisi menurut adanya prestasi. Atkinson (1958:34) mengemukakan bahwa keberhasilan individu untuk mencapai keberhasilan dan memenangkan persaingan berdasarkan standar keunggulan, sangat terkait dengan tipe kepribadian yang memiliki motif berprestasi lebih tinggi daripada motif untuk menghindari kegagalan begitu pula sebaliknya, apabila motif menghindari terjadinya kegagalan lebih tinggi daripada motif sukses, maka motivasi berprestasi seseorang cenderung rendah.

Kelompok siswa yang memiliki motivasi berprestasi tinggi memperoleh hasil belajar pemahaman dan penerapan konsep lebih baik, siswa bermotivasi berprestasi tinggi akan selalu bekerja keras, tangguh, tidak mudah putus asa, ingin mendapat prestasi yang lebih tinggi, khawatir akan kegagalan, berorientasi ke masa depan, menyenangi tugas yang sulit, menyukai umpan balik cepat tentang prestasinya, juga bertanggungjawab dalam memecahkan masalah.

\section{Pengaruh interaksi umpan balik dan motivasi berprestasi terhadap hasil belajar.}

Interaksi adalah kerja sama dua atau lebih variabel bebas dalam mempengaruhi suatu variabel terikat (Kerlinger, 1986). Pengaruh interaksi adalah pengaruh bersama (joint effect) dua atau lebih variabel bebas terhadap variabel terikat. Berdasarkan tabel hasil pengujian multivariat, diperoleh hasil bahwa strategi umpan balik dan motivasi berprestasi memiliki pengaruh yang signifikan secara simultan terhadap variabel hasil pemahaman dan penerapan konsep. Namun tidak pada interaksi keduanya. Hasil pengujian Manova dalam menguji ada atau tidak interaksi antara strategi umpan balik dan motivasi berprestasi menunjukkan bahwa angka signifikansi yang diperoleh pada skor hasil belajar pemahaman konsep sebesar 0.639 dan pada skor hasil belajar penerapan konsep sebesar 0.617. Kedua variabel memiliki nilai sig $>0.05$ sehingga disimpulkan bahwa tidak ada interaksi yang bermakna antara strategi umpan balik dan motivasi berprestasi. Strategi umpan balik dan motivasi berprestasi, masing-masing berpengaruh parsial terhadap hasil belajar pemahaman dan penerapan konsep. Pengaruh lebih nyata pada skor hasil belajar penerapan konsep saja ( $\mathrm{sig}<0.05$ ). Hal ini sejalan dengan hasil uji beda rata-rata sebelumnya.

Analisis ada atau tidak ada interaksi antara strategi umpan balik dan motivasi berprestasi dapat dijelaskan, bahwa ketika guru memberikan penghargaan dalam bentuk konkret sebagai sebuah umpan balik, maka motivasi intrinsik tereduksi secara signifikan dan siswa enggan untuk memotivasi atau mengatur diri sendiri. Umpan balik sebagai penghargaan ekstrinsik seringkali mendorong siswa untuk lebih mementingkan insentif, yang akhirnya menyebabkan semakin tingginya intensitas evaluasi dan kompetisi dan bukan tingginya keterlibatan dalam pembelajaran. Teori yang menyatakan bahwa umpan balik berfungsi sebagai motivator atau insentif untuk pembelajaran masih tetap berlaku 
Jurnal PINUS: Jurnal Penelitian Inovasi Pembelajaran, 5 (2), 2020, Sumarno

di kelas-kelas sekarang ini, tetapi muncul kebingungan untuk membedakan antara pujian dan umpan balik yang terkait dengan isi pembelajaran Oleh karena itu, penyesuaian isi, fungsi dan format penyajian umpan balik haruslah didasarkan pada pertimbangan sasaran pembelajaran dan karakteristik siswa untuk memaksimalkan nilai informatif dari umpan balik tersebut. Penggunaan strategi umpan balik juga sangat bergantung pada bagaimana siswa mengolah dan menginterpretasikan informasi yang disediakan. Untuk menarik simpulan tentang pengaruh berbagai strategi umpan balik, maka harus dilakukan pengontrolan bukan hanya pada faktor motivasional dan meta kognitif tetapi juga pada bagaimana individu memproses umpan balik dari guru.

\section{KESIMPULAN DAN REKOMENDASI}

Simpulan hasil penelitian mengungkapkan tiga temuan, yaitu; pertama, ditemukan perbedaan skor pemahaman dan penerapan konsep antara kelompok strategi umpan balik langsung dan tidak langsung. Kedua, ditemukan perbedaan skor pemahaman dan penerapan konsep antara kelompok motivasi berprestasi rendah dan tinggi. Ketiga, interaksi antara strategi umpan balik dengan motivasi berprestasi tidak berpengaruh secara simultan terhadap pemahaman dan penerapan konsep.

Rekomendasi kepada guru mata pelajaran Pendidikan Pancasila dan Kewarganegaraan di sekolah, disarankan untuk menggunakan strategi umpan balik langsung dan tidak langsung untuk mengoptimalkan kemampuan pemahaman dan penerapan konsep peserta didik Strategi umpan balik langsung dan tidak langsung dapat membantu peserta didik mereduksi perbedaan antara hasil pemahaman dan penerapan konsep yang dicapai dengan yang distandarkan oleh guru atau sekolah. Dalam merancang strategi umpan balik yang efektif, faktor penting yang perlu diperhatikan adalah umpan balik harus diorientasikan menjawab tiga pertanyaan yang diajukan oleh guru dan/atau oleh siswa yaitu: (1) apa tujuan (apa sasaran yang akan dicapai?, (2) bagaimana kemajuan saya (kemajuan apa yang sudah dicapai untuk menuju ke sasaran?, dan (3) kemudian apa tujuan berikutnya (aktivitas apa yang perlu dilakukan untuk menciptakan kemajuan yang lebih baik? Rancangan umpan balik guru selain menjawab tiga pertanyaan tersebut, faktor lain yang juga diperhatikan adalah sebagai berikut: (1) format tugas, (2) proses memahami tugas, (3) dimensi proses meta kognitif dan/atau (4) dimensi diri sendiri (yang tidak terkait dengan tugas). Umpan balik memiliki efek-efek yang berbeda pada dimensi-dimensi tersebut. Strategi umpan balik yang efektif memberikan dua jenis informasi pada siswa: yaitu verifikasi dan elaborasi. Verifikasi didefinisikan sebagai penilaian sederhana tentang apakah sebuah jawaban benar atau tidak, dan elaborasi adalah aspek informasional dari pesan tersebut, dan memberikan petunjuk yang relevan untuk memandu siswa memperoleh jawaban yang benar. Rancangan umpan balik yang efektif 
Jurnal PINUS: Jurnal Penelitian Inovasi Pembelajaran, 5 (2), 2020, Sumarno

mengandung informasi verifikasi dan elaborasi.

Saran untuk penelitian yang akan datang tentang kontribusi umpan balik dalam pembelajaran, yaitu: a). penelitian dengan melibatkan subjek dan lokasi lebih banyak dan bervariasi sehingga dapat dilakukan generalisasi; b) penelitian bagaimana umpan balik berfungsi dalam jenis domain belajar selain kognitif tetapi juga pada ranah psikomotor dan afektif; c) penelitian bagaimana umpan balik berfungsi dalam lingkungan belajar dengan paradigma konstruktivist serta menguji strategi umpan balik baru dalam lingkungan tersebut; dan d) dikaitkan dengan teknologi yang terus berkembang dapat dikaji bagaimana desain umpan balik yang efektif berbantuan teknologi untuk peningkatan hasil pembelajaran.

\section{DAFTAR RUJUKAN}

Anderson, L.W. Krathwohl, D.R. 2001. A Taxonomy for

Learning,Teaching, and Assessing. New York: Logman.

Arends, R.L. 2008. Learning To teach. Seventh Edition. New York: McGraw Hill Companis.Inc.

Atmadi, A \& Setyaningsih, Y. 2004. Transformasi Pendidikan Memasuki Milenium Ketiga. Yogyakarta: Penerbit Kanisius Universitas Sanata Dharma.

Birgit Harks. 2014. The effects of feedback on achievement, interest and self-evaluation: the role of feedbacks perceived usefulness.Educational Psychology, (OnlineVol. 34, No. 3, pp 269- 290.(https://www.google.co.id/?g ws_rd=ssl\#q=the+effect + of + feed back+on+achievement $\% 2 \mathrm{C}+$ inter est+and+selfbevaluation:+the+rol e+of+feedback\%27s+pdf), diakses 18 April 2016.

Butler, R. (1987). Effects of different feedback conditions on motivational perceptions, interest, and performance. Journal of Educational Psychology, (Online79(4), 474482(https://www.google.co.id/?g ws_rd=ssl\#q=Effects+of +differe $\underline{\mathrm{nt}+\text { feedback+conditions+on+mot }}$ ivational+perceptions $\% 2 \mathrm{C}+$ intere st $\% 2 \mathrm{C}+\mathrm{and}+$ performance.Journal +of+Educational+Psychology), di akses 20 April 2016.

Butler, Andrew C, dkk. 2007. The Effect of Type and Timing of Feedback on Learning From MultipleChoice Tests, Journal of Experimental Psychology, (Online), Vol. 13, No. 4, pp 273281(https://www.google.co.id/?g ws_rd $=$ ssl\#q=the+effect + of + type + and+timing + of + feedback + on +1 earning+from+multiplechoice+tests+pdf), diakses 18 April 2016.

Brookart, Susan,M. 2006. How to give effective feedback to your students. Alexandra Virginia USA: Association for supervision and Curriculum Development (ASCD).

Degeng, Nyoman. S. 2013. Ilmu Pembelajaran. Bandung: Kalam Hidup. 
Jurnal PINUS: Jurnal Penelitian Inovasi Pembelajaran, 5 (2), 2020, Sumarno

Gagne, R.M. 1985. The Conditions of Learning. Fourth edition. New York: CBS College Publishing.

Gopal and Patil, S.S. 2015.Effectiveness of Juriprudential Inquiry Model of Teachhing on The Academic Achievement of Social Science Among secondary School Student.International

Multidciplinary Research

Journal, (Online), Vol. 4. Nomor.12 Hal.1-5, (https://www.google.co.id/?gws_ $\mathrm{rd}=\mathrm{ss} l \# \mathrm{q}=$.Effectiveness+of + Juri prudential+Inquiry+Model+of $+\mathrm{T}$ eachhing+on+The+Academic $+\mathrm{A}$ chievement+of+Social+Science+ Among+secondary+School+Stud entisrj.org/Article.aspx?ArticleID =5886), diakses 10 April 2016 .

Joyce. B dan Weil. M. 2003. Models of Teaching. Fith Edition.New Delhi: Prentice-Hall of India.

Hatie, J. and Helen Timperley. 2007. The Power of Feedback. Review of Educational Research, (Online), Vol. 77, No. 1, pp. 81-112, (https://www.google.co.id/education.qld. gov.au/staff/development/.../powerfeedback.pdf), diakses 12 April 2016.

Haiti, J. and Mark Gan, 2011. Intruction Based on Feedback Hanbook Research on Learning and Instrauction, Chapter 13, pp. 249-270

Hailikari, Telle. 2009. Assessing University Students Prior Knowledge Implications for Theory and Practice.University of Helsinki Deparement of Education. Research Report 227, (Online), Halaman:6, (https://helda.helsinki.fi/bitstream/handle /10138/19841/assessin.pdf), diakses 20 April 2016.

Kulik, J. A., \& Kulik, C. C. 1988. Timing of feedback and verbal learning. Review of Educational Research, (Online),58(1), 79-97, (www.epsteineducation.com/hom e/articles/file/research/RoleFeedb ack.pdf), diakses 18 April 2016.

Marieke Thurlings, at.all. 2013. Understanding feedback: A learning theory perspective. Journal homepage:Computers \&Education 9, (Online), pp. 1-15, (www.sciencedirect.com/science/ .../S1747938X12000656), diakses 10 April 2016

Marzano,R.J, Pickering,D.J dan Pollock, J.E.2004.Classroom Instruction that Works: Reseacrh-Based Strategies For Increasing Student Achievement. Chapter 8.Halaman.92

Moreno, R. 2004. Effects of explanatory versus corrective feedback in discovery-based multimedia. Instructional Science, (Online),32,99113(https://books. google.co.id/books?isbn=052183 8738diakses 21 April 2016.

Mory, E. Holland. 2011. Feedback Research Rivisited. Handbook of Research for Educational Communication and Technologi, (AECT) T, Chapter 29, pp 919956,

(www.aect.org/edtech/ed1/29.pdf ), diakses 14 April 2016.

Narciss, Susanne. 2010. Feedback Strategies for Interactive Learning Tasks. Handbook of Research for 
Jurnal PINUS: Jurnal Penelitian Inovasi Pembelajaran, 5 (2), 2020, Sumarno

Educational Communication and Technologi, (OnlineChapter 11, pp 126-140

(www.aect.org/edtech/ed1/11.pdf ), diakses 13 April 2016.

Nwafor,C.E. 2014. Use of Jurisprudential Innovative Approach in teaching Basic Science: An alternative to Lecture Methode. International researchers, (Online), Vol. 3.Nomor.1.Hal. 62-67, (http://iresearcher.org/Current\%20Issue $\% 20$ Volume $\% 20$ No.3\%20Issue $\% 20$ No. 1.html), diakses 9 April 2016.

Santoso, S. 2014. Statistik Parametrik: Konsep dan aplikasi SPSS. Jakarta: PT. Elex Media Komputindo.

Setyosari, $\quad$ P.2013.Strategi penelitian Pendidikan dan Pengembangan. Jakarta: Kencana prenadamedia Group.

Sichinga, K.T. dkk. 2014. Factors Influencing quality of Feedback in Teaching in Botswana Senior Secondary Schools. International Journal of Research In Social Sciences, (OnlineVol. 4, No.1, pp. 26-37, (www.ijsk.org/uploads/3/1/1/7/3117743/ 3 _feedback_and_learning.pdf), diakses 16 April 2016.

Sugiyono, 2014. Statistika untuk Penelitian. Bandung: Alfabeta.
Shute, Valerie. J. 2008. Focus on Formative Feedback. Review of Educational Research, (Online), Vol.78, No.1, pp. 153-159, (https://www.ets.org/Media/Rese arch/pdf/RR-07-11.pdf), diakses 15 April 2016.

Veer Pal, Singh. 2010. Effectiveness of Jurisprudential Inquiry Model of Teaching on Value Inclination of School Students, Journal of Educational Research.,(Online), Volume 47 Number 2 Hal. 45-71, (https://www.google.com/search? $\mathrm{q}=$ Veer $+\mathrm{Pal} \% 2 \mathrm{C}+$ Singh.+2010. Journal+of+Educational+Researc h.\%2C+Volume+47++Number +2 $\% 2 \mathrm{C}++$ Hal. $+45-71 . \&$ ie $=$ utf8\&oe=utf-8), diakses 17 April 2016.

Voerman, L. at.al. 2012. Types and frequencies of feedback interventions in classroom interaction in secondary education. Journal hompage: Teaching an Teacher education, (Online), xxx.19(https://www.google.com/search ?q=Voerman\%2C+L.+at.al.+201 2.+Types + and + frequencies + of $+\mathrm{f}$ eedback+interventions+in+classr oom+interaction+in+secondary+ education), diakses 16 April 2016. 